\title{
Microarray analysis and quantitative real-time $P C R$ validation of gene expression during auditory hair cell regeneration in zebrafish (Danio rerio)
}

\author{
Julie B Schuck ${ }^{1}$, Chia-Hui Lin ${ }^{1}$, William T Penberthy ${ }^{1}$, Xiaohong Li², \\ Nigel GF Cooper ${ }^{2}$ and Michael E Smith*1
}

\author{
Address: ${ }^{1}$ Department of Biology and Biotechnology Center, Western Kentucky University, Bowling Green, KY 42101, USA and ${ }^{2}$ Department of \\ Anatomical Sciences and Neurobiology, University of Louisville, Louisville, KY, 40292, USA \\ Email: Michael E Smith* - michael.smith1@wku.edu \\ * Corresponding author
}

from UT-ORNL-KBRIN Bioinformatics Summit 2009

Pikeville, TN, USA. 20-22 March 2009

Published: 25 June 2009

BMC Bioinformatics 2009, I0(Suppl 7):A12 doi:I0.II86/I47|-2105-I0-S7-A I2

This abstract is available from: http://www.biomedcentral.com/I47I-2/05/I0/S7/AI2

(C) 2009 Schuck et al; licensee BioMed Central Ltd.

\section{Background}

Fishes are capable of regenerating sensory hair cells in the inner ear after acoustic trauma [1]. We recently established the time course for auditory hair cell regeneration in zebrafish. Immediately following acoustic overexposure, zebrafish saccules exhibited significant hair cell loss, but recovered to pretreatment levels at 14 days post-sound exposure [2]. Cell proliferation peaked two days postsound exposure (dpse), so we examined gene expression patterns before, during, and after this time to find genes associated with this proliferation and subsequent hair cell regeneration.

\section{Materials and methods}

Three groups of 18-20 adult zebrafish were exposed to a $100 \mathrm{~Hz}$ pure tone at $179 \mathrm{~dB}$ re $1 \mu \mathrm{Pa}$ RMS for 36 hours to cause acoustic trauma. The whole inner ears of each fish were removed and pooled for RNA extraction at 0,2 , and 4 dpse. Microarray analysis was used to examine expression levels of candidate genes known to regulate hair cell development and to search for new, as yet, unknown candidate genes. Fluorescent cRNA from each treatment sample was hybridized to three duplicate Agilent Zebrafish oligonucleotide arrays $(4 \times 44 \mathrm{~K}, 60$-mer oligo-nucleotides). Subsequently, significantly regulated genes were validated using quantitative real-time PCR (Q-RT-PCR).

\section{Results}

Microarray analysis showed that a number of genes are significantly regulated in the sound-exposed zebrafish inner ear at 2 and 4 dpse. There were no significant changes in expression levels of Atonal $1 \mathrm{~A}$, JunB, Rb, nor CDKN1A but there were several other genes with altered expression levels. These results were validated using quantitative real-time PCR (Q-RT-PCR; Figure 1). A greater than 30-fold increase in growth hormone was seen at 2 dpse in direct correlation with saccular cell proliferation. Meanwhile two myosin heavy chain genes (atrial and smooth muscle) were repressed by comparable magnitudes at 2 and 4 dpse.

\section{Conclusion}

A number of genes were either up- or down-regulated at 2and 4-dpse. Our qrtPCR validation confirms the gene patterns found in our microarray results. Putative biological processes such as proliferation and differentiation for some of these genes have been identified, but more work will be needed to determine the importance of many of them, including the role of growth hormone in stimulating inner ear hair cell regeneration.

\section{Acknowledgements}

This research was supported by NIH grant P20 RR-1648I, an NSF-EPSCoR grant, and a WKU faculty scholarship to M.E.S. 


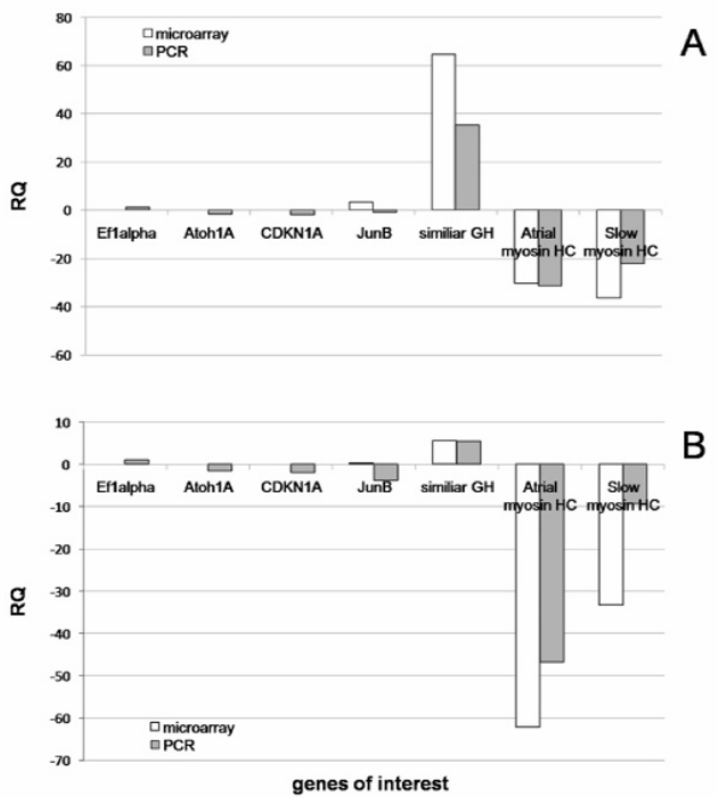

Figure I

Quantitative real-time PCR validation of some of the genes shown to be regulated by the microarray experiment at (A) 2 days and (B) 4 days post-sound exposure relative to controls. Eflalpha was used as a housekeeping gene control.

\section{References}

I. Smith ME, Coffin AB, Miller DL, Popper AN: Anatomical and functional recovery of the goldfish (Carrasius auratus) ear following noise exposure. J Exp Biol 2006, 209:4193-4202.

2. Schuck JB, Smith ME, Li X, Cooper NGF: Microarray analysis of gene expression during auditory hair cell regeneration in zebrafish (Danio rerio). BMC Bioinformatics 2008, 9(Suppl 7):PI5.
Publish with Bio Med Central and every scientist can read your work free of charge

"BioMed Central will be the most significant development for disseminating the results of biomedical research in our lifetime. "

Sir Paul Nurse, Cancer Research UK

Your research papers will be:

- available free of charge to the entire biomedical community

- peer reviewed and published immediately upon acceptance

- cited in PubMed and archived on PubMed Central

- yours - you keep the copyright 